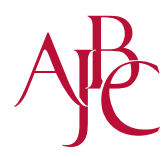

\title{
The Investigation of Function of Mineral Mud for the Skin
}

Yijie Du, Xiaofeng Deng, Li Li, Yinmao Dong*

Department of Cosmetic Science and Technology, Beijing Technology and Business University, Beijing, China

\author{
*Corresponding author: Yinmao Dong, \\ Department of Cosmetic Science and \\ Technology, College of Science, Beijing \\ Technology and Business University, \\ No. 11/33, Fucheng Road, Haidian \\ District, Beijing, China \\ Tel. : +861068984937 \\ Email: ymdong2008@163.com
}

Received February 17, 2016

Revised March 19, 2016

Accepted March 24, 2016

Published March 30, 2016

\begin{abstract}
Purpose: The treatment of mineral mud in rheumatic disease, psoriasis and other disease has been widely recognized in clinic application. We aim to explore the effect of mineral mud on the skin through it clinic application. Methods: We summarize the function of mineral mud in anti-inflammation, anti-oxidation, et al and point out the existing in the application of mineral mud in cosmetics and its development status. Results: Mineral mud have positive effects on rheumatic diseases through its properties of anti-inflammatory and antioxidation. Conclusion: The results demonstrate that mineral mud had a good prospect in cosmetics, but there are still many problems to be solved.
\end{abstract}

Keywords: Skin, Cosmetics, Mineral mud, Anti-inflammation, Antioxidation

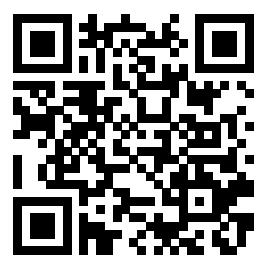

大的开发潜力，鉴于此，笔者把矿物泥对皮肤的作用做一综

\section{Introduction}

矿物泥是经过长期的地质活动, 多年矿化而形成的, 矿泥 的化学成分极为复杂, 含有多种矿物质, 但是不同地区所 形成的矿物泥(Qin et al., 2012)中矿物质的含量也有一定差 别。矿物泥独特的剂型以及功效使得矿物泥在人类医疗、保 健、美容史上得到了广泛的应用, 通过调研不同地区矿物泥 (如Table 1.) (Qin et al., 2012; Wang \& Xie, 2007; Du \& Sun, 2006）发现其中五大连池矿物泥的临床应用最为突出。矿 泥疗法就是通过饮用矿水、洗浴矿水、用矿泥涂抹周身或者 全身浸泡于矿泥中, 再配合日光照晒的治疗方法 (Wang \& Wang, 2001）。矿泥疗法的民间应用已有百余年历史, 对于 风湿性疾病、银屑病等多种难以根治的疾病取得了很好的临 床效果, 并对其作用及机理进行了一定程度的研究, 但是目 前为止对于矿物泥的美容作用还没有进行过系统的研究与报 道。随着人们对天然、绿色、健康、安全产品的迫切向往, 现在 “崇尚绿色, 回归自然” 已成为化妆品领域的主流思 想, 这也使得矿物泥这种 “源于自然” 的天然矿产资源有很

\section{述, 以期为矿物泥在化妆品中的应用提供参考。}

\section{The function of mineral mud on skin}

\section{Anti-inflammatory effect of mineral mud on skin}

通过研究矿泥疗法的民间应用, 我们发现泥疗的临床应用 主要集中在关节病、糖尿病、颈椎-腰椎病、皮肤病等方面

(Qin et al., 2011)，对于矿物泥临床机理的研究主要集中在 关节炎相关疾病上, 通过调研发现, 矿物泥的作用机理与抗 炎有很大关系。

实验研究发现（Xiao et al.,2002），矿物泥提取物能够有效抑 制前列腺素2 (PGE2) 的释放, 其作用机理可能与花生四烯 酸代谢过程中环氧化酶（COX）的抑制作用有关。PCE2 在炎 症过程中可通过协同趋化因子激活及吸引中性粒细胞等促进 炎症反应发生发展（Deng et al., 2008）。同时也有实验研究 显示矿物泥能够抑制TNF- $\alpha, I L-1 \beta$ 等炎症因子以及MMPs的释 
放。

肖长虹等人（Xiao et al., 2003）通过观察热矿泥浴对大鼠 佐剂诱导性关节炎 (AIA) 的治疗效果及作用机制, 发现其 机制与抑制血清肿瘤坏死因子（TNF- $\alpha$ ）的产生以及基质金 属蛋白酶-1（MMP-1）的表达有关。Bellometti S等人试验

（Bellometti et al., 2002）也表明, 矿物泥能有效降低IL-1ß、 TNF- $\alpha$ 以及TNF- $\alpha$ 可溶性受体的表达。Bellometti S (Bellometti et al., 2005)实验验证, 泥浴治疗后风湿病患者血清中的 MMP-3水平有显著降低。研究显示, 这些细胞因子也会引起 皮肤相关炎症, 所以推断矿物泥有减少皮肤炎症的潜力, 而 具体影响机制还有待进一步科学验证。

TNF- $\alpha$ 是一种强力促炎症反应细胞因子, 存在于机体任何炎 症产生部位。许多体外刺激可以影响TNF- - 水平的升高, 如 UVB可使永生化角质形成细胞、角质形成细胞、皮肤肥大细 胞的TNF-a水平显著升高（Kanget al., 1998; Konda \& Jimbow, 1998）。研究显示, TNF- $\alpha$ 能够显著抑制皮肤成纤维细胞的 增殖与迁移, 抑制I 型胶原蛋白的表达（Yu et al., 2012）。 实验通过体外培养原代人皮肤成纤维细胞, 以 $10 \mu \mathrm{g} / \mathrm{L} \mathrm{TNF}-a$ 作用 $24 \mathrm{~h}$, 用细胞计数试剂盒观察细胞增殖, 用细胞划痕愈
合实验观察成纤维细胞的迁移, 用Western blotting法研究 | 型胶原蛋白的表达, 结果显示: TNF- $\alpha$ 能显著抑制皮肤成纤 维细胞的增殖与迁移, 通过Western blotting发现TNF- $\alpha$ 还能 抑制Ｉ型胶原蛋白的表达（Yu et al., 2012）。TNF- $\alpha$ 可诱导 血管内皮细胞产生白细胞秥附分子、IL-8等炎性介质, 从而 直接和间接导致血管内皮细胞的损伤和调亡 (Chang \& Chen, 2009）。有实验研究发现, 通过用不同浓度的TNF- $a$ 刺激体 外培养的人肺静脉血管内皮细胞6、12、24、48h，检测细胞 凋亡情况, 实验结果表明: TNF- $\alpha$ 能诱导内皮细胞NO、sFas 的合成和内皮细胞的凋亡, 并呈时间、剂量依赖性（Zhou et al., 2004）。血管内皮细胞的调亡，从而引起内皮依赖性 血管舒张功能、弹性功能降低, 进而影响血管张力和器官灌 流, 最终影响血红蛋白的数量, 从而对皮肤的颜色照成影 响。TNF- $a$ 可活化T细胞, 诱导角质形成细胞和血管内皮细胞 表达细胞间隸附分子（ICAM-1），从而提供了中性粒细胞与 淋巴细胞的黍附位点, 活化中性粒细胞与血管内皮细胞引起 机体强烈的炎症反应, 增加IL-1、IL-6、IL-8的释放 (Chang \& Chen, 2009）。这些都提示了TNF- $a$ 对皮肤的作用，同时也提 示了矿物泥抗炎作用的效果。

Table 1. Main producing area and characteristics of mineral mud in China

\begin{tabular}{|c|c|c|c|c|}
\hline Name & Source area & Origin & Characteristics & Function \\
\hline $\begin{array}{l}\text { Mineral mud } \\
\text { of wudalianchi } \\
\text { (WM) }\end{array}$ & $\begin{array}{l}\text { Wudalianchi, } \\
\text { heilongjiang } \\
\text { province }\end{array}$ & $\begin{array}{l}\text { WM is through volcanic ash } \\
\text { and mineral water interaction } \\
\text { of immersion, and formed by } \\
\text { long-term weathering and } \\
\text { water natural ripening slime }\end{array}$ & $\begin{array}{l}\text { 1. WM is the world's rare low } \\
\text { temperature cold spring mud } \\
\text { 2. WM has been detected with } \\
\text { more than } 30 \text { kinds of trace } \\
\text { elements and the proportion same } \\
\text { as the body needs } \\
\text { 3. Active components of WM exist } \\
\text { in the form of ions } \\
\text { 4. WM is rich in organic acids and } \\
\text { fatty acids } \\
\text { 5. WM rich in melanin antagonistic } \\
\text { substances - partial silicate ions }\end{array}$ & $\begin{array}{l}\text { Clinical treatment of } \\
\text { rheumatism, rheumatoid } \\
\text { arthritis, hair loss, psoriasis, } \\
\text { peripheral neuritis, psoriasis } \\
\text { and other chronic skin } \\
\text { disease have very good } \\
\text { effect }\end{array}$ \\
\hline $\begin{array}{l}\text { Hainan } \\
\text { volcano mud } \\
(\mathrm{HM})\end{array}$ & $\begin{array}{l}\text { Hainan } \\
\text { province }\end{array}$ & $\begin{array}{l}\text { Eruption product of Qiong } \\
\text { volcano in Hainan province }\end{array}$ & $\begin{array}{l}\text { adsorption performance, suitable } \\
\mathrm{PH} \text { that basically close to human } \\
\text { body }\end{array}$ & $\begin{array}{l}\text { Have not seen a detailed } \\
\text { report }\end{array}$ \\
\hline $\begin{array}{l}\text { Dead sea mud } \\
\text { in Yuncheng } \\
\text { area of Shanxi } \\
\text { province (YM) }\end{array}$ & $\begin{array}{l}\text { Yuncheng, } \\
\text { Shanxi } \\
\text { province }\end{array}$ & $\begin{array}{l}\mathrm{HM} \text { is composed of animal } \\
\text { and plant debris, aquatic } \\
\text { plants, shellfish in the case of } \\
\text { hypoxia after many years of } \\
\text { sedimentation and microbial } \\
\text { action }\end{array}$ & $\begin{array}{l}\text { 1. HM main composition with } \\
\text { sulfate } \\
\text { 2. HM have a good elasticity and } \\
\text { adhesion } \\
\text { 3. In addition to containing a } \\
\text { variety of minerals and trace } \\
\text { elements, containing a variety of } \\
\text { amino acids }\end{array}$ & $\begin{array}{l}\text { 1. HM can improve the skin } \\
\text { moisturizing properties } \\
\text { 2. HM can help clear free } \\
\text { radicals } \\
\text { 3. HM can help to promote } \\
\text { hair growth }\end{array}$ \\
\hline $\begin{array}{l}\text { Sea mud in } \\
\text { Xiushan Island } \\
\text { of Zhejiang } \\
\text { province (XM) }\end{array}$ & $\begin{array}{l}\text { Xiushan } \\
\text { island, } \\
\text { Zhejiang } \\
\text { province }\end{array}$ & $\begin{array}{l}\mathrm{XM} \text { is composed of algae, } \\
\text { crustaceans and aquatic } \\
\text { animal and plant debris after } \\
\text { years of sedimentation }\end{array}$ & $\begin{array}{l}\text { 1. } X M \text { is rich in vitamin } B, A, C \text {. } \\
2 . X M \text { has higher total protease } \\
\text { activity }\end{array}$ & $\begin{array}{l}\text { 1. } X M \text { has antioxidant effect } \\
\text { 2. } X M \text { has inhibitory effect on } \\
\text { tyrosinase } \\
\text { 3. XM has antibacterial effect }\end{array}$ \\
\hline
\end{tabular}


研究显示, IL-1B促进辐射成纤维细胞的MAPK活性和C-Jun氨 基末端激酶（JNK）的mRNA的表达，使UV辐射成纤维细胞 MMP-1表达增加, 从而表明IL-1在真皮胶原过度降解中发挥 着重要作用（Wang \& Bi, 2005）。

基质金属蛋白酶MMPS是一个含锌蛋白酶家族, 其主要生理 作用为降解细胞基质, MMPS几乎能够降解细胞基质中的所 有蛋白成分, 是主要的蛋白水解酶。在很多外部因素的刺激 下, 例如UV照射, 可导致角质形成细胞内部炎症因子的释 放, 从而刺激成纤维细胞跨膜蛋白MMPs的过度表达, 引起 胶原蛋白的降解（Dong \& Li, 2015）。矿泥可能通过抗炎作 用有效降低MMPs的产生, 从而有利于维持真皮层中胶原蛋 白和弹性纤维的含量。

\section{Anti-oxidation effect of mineral mud on skin}

SOD、GSH-PX都是正常细胞中重要的酶促抗活性氧防御体 系, 能够通过清除机体内过量自由基而抑制脂质过氧化反应 （Cho \& Lee, 2013）。MDA是脂质过氧化产物，使胶原蛋白 交联、硬化从而失去膨胀能力, 外观表现皮肤弹性下降, 产 生皱纹。苏潚㴋等人（Su et al., 2009）通过注射D-半乳糖造 成小鼠衰老模型, 分别涂抹纯化水、空白基质、温泉矿泥进 行对照试验, 42 天后, 测定小鼠背部组织均浆中超氧化物 歧化酶（SOD）活力, 过氧化脂质代谢产物丙二醛（MDA） 和皮肤强脯氨酸含量。结果显示温泉矿泥能明显增加小鼠皮 肤羟脯氨酸含量, 升高小鼠皮肤SOD活性, 使其MDA含量下 降，证明矿物泥对皮肤具有一定的抗衰老作用。

同时矿物泥中存在多种微量元素, 这些微量元素都是合成 酶进行反应所必须辅助因子, 能够影响机体进行一系列酶促 反应, 矿物泥的抗氧化作用很可能与其中的微量元素有关。 通过综合比较几种不同成因的矿物泥后发现, 大都富含钾、 钙、钠、镁、铁、锰、锌、铜, 如Table 2. 所示 (Qin et al., 2012; Wang \& Xie, 2007; Du \& Sun, 2006)。钾在细胞的新陈代 谢中起到重要作用, 有助于营养物质进入与废弃物的排出
（Yao et al., 2006），实验研究发现K+浓度的升高可明显减少 活性氧簇（ROS）的形成。镁是机体内诸多酶类的重要辅助 因子之一, 在细胞衰老过程中, 对细胞周期和细胞凋亡有着 调节作用。高芳等人（Gao et al., 2009）通过实验证实, 镁 离子不仅可以保护受到UV辐射损伤的细胞还能促进受损细胞 的修复, 其作用机理可能与提高ROS的清除效率、改善UV介 导的DNA损伤修复效率有关。铜、锌是铜锌超氧化物歧化酶 (CuZn-SOD) 所必需的辅助因子, CuZn-SOD是消除超氧自 由基的关键酶, 同时张文清等人（Zhang \& Hai, 1998）通过 观察锌对大鼠肝微粒体4种脂质过氧化模型的抗氧化作用, 证实锌对大鼠肝微粒体脂质过氧化反应有显著抑制作用。矿 物泥中这些元素的富集, 也可能是矿物泥对机体其作用的因 素之一，但是目前为止，并没有实验证明。

\section{Other effects of mineral mud on skin}

热作用: 矿物泥导热性低, 散热性慢, 保温性能好, 能长 时间保持温度恒定。温热作用使皮肤温度增高, 当人体温度 升高, 机体氧化过程加快, 人体基础代谢会增加, 从而将细 胞代谢产物和各种有害物质及时清除, 保证细胞的良好活 性。

机械作用: 在泥浴过程中，人的皮肤表面会受到矿物泥的 压力作用, 矿泥的压力压迫人体体表血管及淋巴管, 促进体 液的向心回流, 进而促进体液的再分配作用, 从而促进机体 循环。而且利用泥的可塑性、粘滞性和抗剪强度对人体皮肤 形成的重量和压力, 干涸收缩时, 对皮肤产生的压力有一定 的吸附作用, 可清除皮肤表面的污垢、细菌、代谢产物、尘 埃物等（Liet al., 2005）。同时由于泥中含有各种微小砂土颗 粒及大量胶体物质, 当其与皮肤密切接触时, 对机体可产生 一定的摩擦刺激, 有类似按摩的机械效果。

增进心理机能作用: 矿泥浴作为一种特殊的疗养因子有利 于疗养者放松心理, 释放压力, 从而对皮肤美容起到调节 和促进作用。Kuczera M等人（Kuczera \& Kokot, 1996）研究

Table 2. Mineral content in different kinds of mineral mud

\begin{tabular}{|c|c|c|c|c|c|}
\hline $\begin{array}{l}\text { Mineral } \\
\text { content }\end{array}$ & Unit & $\begin{array}{l}\text { Mineral mud of } \\
\text { Wudalianchi }\end{array}$ & $\begin{array}{l}\text { Dead sea mud in Yuncheng } \\
\text { area of Shanxi province }\end{array}$ & $\begin{array}{l}\text { Hainan volcano } \\
\text { mud }\end{array}$ & $\begin{array}{c}\text { Sea mud in Xiushan island of } \\
\text { Zhejiang province }\end{array}$ \\
\hline $\mathrm{K}$ & \multirow{8}{*}{$\mathrm{mg} / \mathrm{kg}$} & 29.00 & 6.10 & - & - \\
\hline $\mathrm{Ca}$ & & 15.20 & 34.10 & 526.00 & 7.00 \\
\hline $\mathrm{Na}$ & & 10.80 & 22.30 & - & - \\
\hline $\mathrm{Mg}$ & & 13.80 & 38.40 & 1.70 & 6.00 \\
\hline $\mathrm{Fe}$ & & 20.20 & 19.40 & 0.96 & 15.00 \\
\hline $\mathrm{Mn}$ & & 1.46 & 0.37 & - & - \\
\hline $\mathrm{Zn}$ & & 0.34 & 0.05 & 7.00 & 0.04 \\
\hline $\mathrm{Cu}$ & & 0.09 & 0.01 & 3.60 & - \\
\hline
\end{tabular}


表明, 热作用可引发一系列的神经内分泌反应, 特别是促 进肾上腺皮质激素 ( ACTH) 、皮质醇、催乳素和生长激素

(GH) 的释放。也有研究表明（Ghersetich et al., 2000）, 矿物泥的热效应能够刺激皮肤产生阿片肽, 从而影响个人情 绪与疼痛阈值。

\section{Conclusion}

随着现代科学技术的发展, 对于矿物泥的研究已经不仅仅 是停留在临床应用上面。然而, 对于矿物泥作用机理的研究 以及矿物泥的产业化发展仍存在以下几方面的问题:

1）虽然在矿物泥的临床应用方面取得了很好的成绩, 但是对于 矿物泥作用并没有系统的研究, 为了使矿物泥的应用更具科学 性、安全性和广泛性, 研究矿物泥具体作用就成为了亟待解决的 问题。

2) 由于矿物泥本身特性决定其研究途径的特殊性, 矿物泥的作 用方式是通过热作用、机械作用、生物活性物质等共同起作用 的, 这就表明人为的把矿物泥割裂开研究并不能体现矿物泥功 效, 所以如何在不损害矿物泥的完整性情况下, 对其作用机理进 行研究也是矿物泥发展的关键性问题。矿物泥形态的特殊性决定 其整体研究无法通过细胞实验来进行，但是动物实验的实验周期 及单因素性都有一定的局限性。3D皮肤模型作为作为一个立体 的皮肤组织, 不受剂型的限制, 而且能更好的观察到细胞形态学 的改变, 如果能够应用到矿物泥的研究中来, 可以对矿物泥有更 全面的研究，但是目前对于矿物泥的3D皮肤模型试验还没有人 进行过报道。

虽然对于矿物泥的研究还存在许多问题, 但是矿物泥长时 间、多案例的临床应用让我们坚信矿物泥有其独特的功效, 所以矿物泥这种天然矿产资源在医学、化妆品领域还是有很 大开发潜力。

\section{References}

Bellometti S, Galzigna L, Richelmi P, Gregotti C, Berte F. Both serum receptors of tumor necrosis factor are influenced by mud pack treatment in osteoarthrotic patients. International Journal of Tissue Reactions, 4: $57-64,2002$.
Bellometti S, Richelmi P, Tassoni T, Berte F. Production of matrix metalloproteinases and their inhibitors in osteoarthritic patients undergoing mud bath therapy. International Journal of Clinical Pharmacology Research, 25: 77-94, 2005.

Bender T, Bariska J, Vághy R, Gomez R, Kovács I. Effect of balneotherapy on the antoxidant system-a controlled pilot study. Archives of Medical Research, 38: 86-89, 2007.

Chang XP, Chen $\mathrm{H}$. The role of $\mathrm{TNF}-\alpha$ in the pathogenesis of skin diseases. Chinese Journal of Dermatovenereology of Intergrated Traditional and Western Medicine, 8: 62-64, 2009.

Cho CH, Lee HJ. Oxidative stress and tardive dyskinesia: pharmaco-genetic evidence. Progress in NeuroPsychopharmacology \& Biological Psychiatry, 46: 207-213, 2013.

Deng JG, Hao EW, Zheng ZW, Yang K, Yan L. Effect of mangiferin on the content of PGE2 in two different inflammation models. Chinese Archives of Traditional Chinese Medicine, 26: 2085-2086, 2008.

Dong YM, Li L. Study on the development of scientific whitening and safe effective compound plant whitening agent. China Cosmetics Review, 2: 40-44, 2015.

Du SY, Sun PX, Li J, Huo WH. Study on mineral black mud from Shanxi Yuncheng salt lake. Detergent \& Cosmetics, 29: 18-21, 2006.

Gao F, Guo ZY, Zeng CC, Wang R, Liu ZM, Zhai J, Meng $\mathrm{P}$. The protective effect of magnesium ion on cultured cells with ultraviolet radiation. Acta Laser Biology Sinica, 4: 470-474, 2009.

Ghersetich I, Freedman D, Lotti T. Balneology today. Journal of the European Academy of Dermatology and Venereology, 14: 346-348, 2000.

Kang K, Gilliam AC, Chen G, Tootell E, Cooper KD. In human skin UVB initiates early induction of $\mathrm{IL}-10$ over IL-12 preferentially in the expanding dermal monocytic/macrophagic population. Journal of Investigative Dermatology, 111: 31-38, 1998.

Konda S, Jimbow K. Dose-dependent induction of IL12 but not $\mathrm{IL}-10$ from human karatinocytes after exposure to ultraviolet light A. Journal of Cellular Physiology, 177: 493-498, 1998. 
Kuczera M, Kokot F. The influence of spa therapy on endocrine system. Polskie Archiwum Medycyny Wewnętrznej, 95: 21-8, 1996.

Li GL, Chen LS, Cui LH, Shao WZ, Yu HX. Analysis of the action mechanism of black mud bath. China Surfactant Soap and Detergent Industries, 5: 77-78, 2005.

Qin JF, Li ZX, Lou MT. Soil therapy in China: Treating diseases (Part one). Guangdong Trace Element Science, 18: 1-29, 2011.

Qin JF, Li ZX, Lou MT. Soil therapy in China: Beauty articles (Part one). Guangdong Trace Element Science, 19: 1-46, 2012.

Su XX, Zeng FB, Zhao SJ, Sun X, Wang H, Hu MH. Experimental study on anti skin aging effect of mineral mud in hot spring. Herald of Medicine, 28: 856-859, 2009.

Wang XY, Bi ZG. Study of the mechanism of $\mathrm{IL}^{-1}$ on MMP production of UVA-irradiated fibroblasts. The Chinese Journal of Dermatovenereology. 19: 513529, 2005.

Wang XY, Xie ZH. Determination of trace elements in the mud in Wudalianchi. Study of Trace Elements and Health, 24: 69, 2007.

Wang XZ, Wang XY. The formation, characteristics, protection, development of Wudalianchi volcano mud.
Geology in Heilongjiang, 12: 9-18, 2001.

Xiao $\mathrm{CH}$, Lin $\mathrm{JH}, \mathrm{Xu} \mathrm{MC}$. The mechanism of thermal mineral mud on experimental rabbit knee osteoarthritis. Chinese Journal of Clinical Rehabilitation, 6: 2542-2545, 2002.

Xiao CH, Wu QF, Zhou YL, Zhou YL, Lin JH, Xu MC, Chen YY. The effects and mechanism of thermal mineral mud-bath in the treatment of adjuvantinduced arthritis in rats. Chinese Journal of Physical Medicine and Rehabilitation. 25: 202-205, 2003.

Yao YP, Feng HB, Zhao LP, Wang YL, Xu SQ. Relationship between internal and external potassium distribution and human health. Journal of Public Health and Preventive Medicine, 1: 57-59, 2006.

Yu HM, Hu HY, Wu X, FANG HY. EGCG attenuates the inhibitory effect of high TNF- $\alpha$ level on the process of wound healing in dermal fibroblasts. Chinese Journal of Pathophysiology, 28: 155-158, 2012.

Zhang WQ, Hai CX. Experimental study of antioxidation of zinc on rat liver microsomal lipid peroxidation model. Journal of Preventive Medicine of Chinese People's Liberation Army, 4: 250-254, 1998.

Zhou YF, Liu ZH, Cheng XJ, Yang XJ. Effects of TNF$\alpha$ to apoptosis of endothelial cells. Suzhou University Journal of Medical Science, 24: 620-623, 2004. 


\section{국문초록}

\section{미네랄머드의 피부작용에 대한 연구}

두일걸, 등소봉, 리려, 동은묘*

북경공상대학 화장품과학기술학과, 북경, 중국

목적: 본 연구는 미네랄머드가 류머티스성 질환, 건선 등 질병에 민간적 응용과 임상적 응용으로 많이 사용됨에 따라 미네랄머드의 피부 임상응용을 목적으로 연구를 진행하였다.

방법: 미네랄머드의 소염, 항산화 작용을 요약하고, 미네랄머드를 화장품에 응용함에 있어서 존재하는 문제를 발견하고 화장품영역 에서의 발전방향을 제시하였다.

결과: 류머티스성 질환, 건선 등 난치 성 피부병의 치료는 미네랄머드의 소염, 항산화작용에 의한 것으로 보인다.

결론: 미네랄머드가 화장품 소재로서의 희망적인 가능성을 가지고 있지만 화장품 완제품으로 개발하기 위해서는 아직도 해결해야 할 여러 문제점들이 있다고 사료된다.

핵심어: 피부, 화장품, 미네랄머드, 소염, 항산화 


\section{中文摘要}

\section{矿物泥对皮肤作用的探讨}

杜一杰, 邓小锋, 李丽, 董银卯*

中国北京工商大学化妆品科学与技术科, 北京, 中国

目的: 矿物泥在治疗风湿性疾病、银屑病等疾病中有悠久的民间应用与临床实践, 并得到了广泛认可, 旨在通过矿物泥的临床应 用, 探索其对皮肤的作用。

方法: 总结了矿物泥在抗炎、抗氧化等方面的作用, 指出了矿物泥在应用中存在的问题, 展望了矿物泥在化妆品领域的发展方 向。

结果: 矿物泥治疗风湿性疾病等疑难皮肤病的治疗效果可能是通过抗炎、抗氧化来实现的。 结论: 矿物泥在化妆品中有良好的应用前景, 但仍有许多问题亟待解决。

关键词: 皮肤, 化妆品, 矿物泥, 抗炎, 抗氧化 